原著

\title{
スワーリング検査不合格な濃厚血小板の発生頻度とその性状
}

\author{
秋野 光明 藤原 満博 佐藤 典宏 本間 稚広 \\ 若本志乃舞 山本 定光 池田 久實 \\ 北海道赤十字血液センター
}

(平成 15 年 1 月 20 日受付)

(平成 15 年 4 月 9 日受理)

\section{FREQUENCY AND CHARACTERISTICS OF SWIRLING NEGATIVE PLATELET CONCENTRATES}

\author{
Mitsuaki Akino, Mitsuhiro Fujihara, Norihiro Sato, Chihiro Homma, \\ Shinobu Wakamoto, Sadamitsu Yamamoto and Hisami Ikeda \\ Hokkaido Red Cross Blood Center
}

\begin{abstract}
We have introduced the swirling test as a routine quality control of individual platelet concentrates (PC), in use since 1995 . Of PC (127,623 bags) examined in the last six years, $82(0.064 \%)$ failed the swirling test. The swirling-negative $\mathrm{PC}$ bags tended to be obtained when 1) a certain apheresis machine was used for PC collection, 2) the PC donor was female and 3) the PC was obtained from a donor whose PC was swirling-negative at a previous donation. Of $141 \mathrm{PC}$ donation from 12 such donors, $36 \mathrm{PC}$ bags $(25.5 \%)$ showed negative swirling.

While swirling-negative PCs showing normal $\mathrm{pH}$ originally maintained their normal range for five days, the extent of their platelet shape change and morphology scores were significantly lower than those of normal PCs. There were no significant differences in aggregation activity or in the expression of activation markers (P-selectin and beta-TG).

The cause of this type of negative swirling is unknown at present. The fact that PCs repeatedly showed negative swirling from the same donors suggest that a factor $(\mathrm{s})$ of the donors may be associated with the loss of swirling.
\end{abstract}

Key words : Swirling, Platelet concentrates

\section{はじめに}

濃厚血小板（platelet concentrates, PC）にはス ワーリングと呼ばれる特有の現象が観察され る $^{1) \sim 4)}$. スワーリングとは, PCの入ったバッグを 光にかざして，ゆっくりと摚拌すると渦巻き状の パターンが見られる現象をいう。これは, 無刺激 の血小板の形態は円盤状であり, 攪拌時, 円盤状 血小板が光を一様に屈折する光散乱現象（スワー リング）をおこすためであると言われている。し かし，血小板の形態が変化すると一様な屈折が生
じないためスワーリングが低下し消失する．この ことは, PC の光散乱現象の有無が血小板の形態 と密接に関係し, 血小板の状態を反映しているこ とを示している．また，PC中に含まれる円盤状血 小板の割合は生体内の寿命と相関すると言われて いる ${ }^{5)}$. 従って PC のスワーリング検査は, PC 中 の血小板の形態を外観の観察によって確認するこ とができるため, サンプル採取することなく, PC の品質を簡便かつ短時間に把握できる有用な方法 である。 
ISBT (International Society of Blood Transfusion) の, BEST (Biomedical Excellence for Safer Transfusion) Working group は，スワーリング検 査が PC の品質保証の方法として有効か否か評価 し4，さらにルーチンでスワーリング検査を実施 して検査不合格の発生状況等を調べたところ, PC の品質管理手段として有用であるとしている ${ }^{6}$. 北海道赤十字血液センター(以下，当センター) で は, その検討結果を基に, 平成 7 年 4 月よりスワー リング検査を導入し，製剤部門から供給部門への 出荷時及び供給部門から医療機関へ供給する前に 同検查を実施することとした．本稿では，平成 7 年 4 月から平成 13 年 3 月までの 6 年間において, 製剤部門から供給部門への出荷時の検査でスワー リング不合格となった PCの発生状況と不合格 $\mathrm{PC}$ の性状について検討した結果を報告する。

\section{方 法}

（1）PC 調製法

成分採取装置を用いて，5〜20 単位の PC を採 取した。採取後 PC は成分採血キットに付属のポ リオレフィン製 PC 保存用バッグ, 或いは $600 \mathrm{ml}$, $1,000 \mathrm{ml}$ のポリオレフィン製バッグ（KBP-600CP または KBP-1000CP, カワスミ化学工業, 東京)で 水平振盪保存した。

（2）スワーリング検査方法

日常業務におけるスワーリング検査では，ス ワーリング陰性のPC を確実に除外することが目 的であることから，判定は 2 名で行い，合格と不 合格の 2 段階で評価したＰCバッグを判定者 2 名が別々に白色光源下 $(50$ ～100W $)$ にかざしなが ら軽く摇らし，30～70cm の離れた距離からバッ グ内にみられるスワーリングパターンを観察し た. 2 名の判定が不一致のときは, 他の観察者が再 検査を行い，その結果を採用した。 なお，スワー リング検査は採血翌日に行った。

（3）スワーリング検査不合格 PC の血小板機能 検查

スワーリング検査で不合格と判定された PCに ついては, 可能な限り判定直後に $\mathrm{pH}$ を測定し 7.0 以上を示した PCについて，血小板機能の測定を 行い, 合格 PC と比較した。
血小板数は自動血球計数装置 (Sysmex K-2000 または K-4500，シスメックス，神戸)で測定した。 $\mathrm{pH}$ は pH メーター (pH meter model COM-8, 電気 化学計器, 東京) を使用し $22^{\circ} \mathrm{C}$ で測定した。血小 板の形態 (Morphology score) は，2.5\% グルター ルアルデヒド/PBS 溶液 (片山化学，大阪) で血小 板を固定し，位相差顕微鏡 (OLYMPUS BX50, 才 リンパス光学，東京）を用いて観察し，血小板の 形態をKunicki らの方法に準じて 4 段階に分類 して円盤状血小板が全体に占める割合（\% discs）を算出した，血小板機能の測定は，自己血 漿で血小板数を $30 \times 10^{4} / \mu l$ に調製した platelet rich plasma（調製 PRP）を用いて行った。凝集能 は $\mathrm{CaCl}_{2}$ 存在下 $5 \mu \mathrm{g} / \mathrm{ml}$ コラーゲン (Horm 社) あ

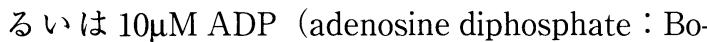
ehringer 社) を加えたときの最大凝集率（\%)を ヘマトレイサー 801 (二光バイオサイエンス社, 東 京）を使用して求めた。低浸透圧ショック回復率 （\%HSR）は調製 PRP に $1 / 3$ 容量の蒸留水を加え， 分光光度計（Hitachi U-2000, 日立，東京）で 610 $\mathrm{nm}$ の透過度の変化を測定し, 添加直後の最大值 と 5 分間後の回復率の比を求百分率（\%) で示 した. 変形能 (Extent of platelet shape change) は Chrono-Log 凝集メーター（AHS ジャパン社，東 京)を使用し, $500 \mu l$ の調製 PRP に最終濃度 $5 \mathrm{mM}$ の EDTA (ethylene diaminotetra acetic acid) を加 え，さらに $\mathrm{ADP}$ を最終濃度 $10 \mu \mathrm{M}$ 加えたときの 透過度の変化率で表した. $\beta$-トロンボグロブリン ( $\beta$-TG： $\beta$-thromboglobulin) は, 専用測定試薬アセ ラクロム $\beta-\mathrm{TG}$ (ロッシュ・ダイアグノスティック ス社，東京）を用い EIA 法で測定した。血小板膜 糖蛋白である P-セレクチン (CD62P) はモノク ローナル抗体（宝酒造，京都）を用い，フローサ イトメーター, オーソ・サイトロン（オーソ・ダ イアグノスティック・システムズ，東京）で血小 板表面の P-セレクチン陽性率を求めた ${ }^{8)}$ 。無菌試 験には好気性菌，嫌気性菌を同時に培養可能な培 養システム (オクソイド「シグナル」)を使用した。

(4) 統計処理

製剤名別，年齢別でみたスワーリング検査不合 格 PC 数の有意差検定には, 独立性の検定を行い, 
Table 1 Frequency of swirling-negative PC classified by PC product

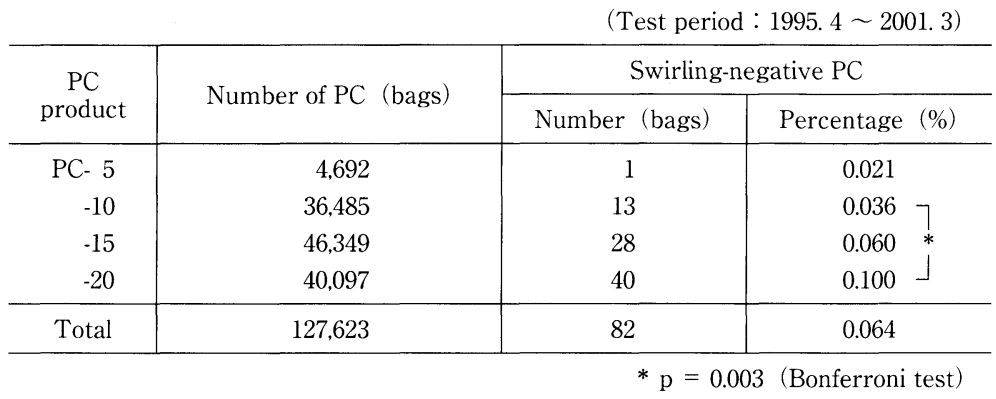

Table 2 Frequency of swirling-negative PC classified by apheresis equipment

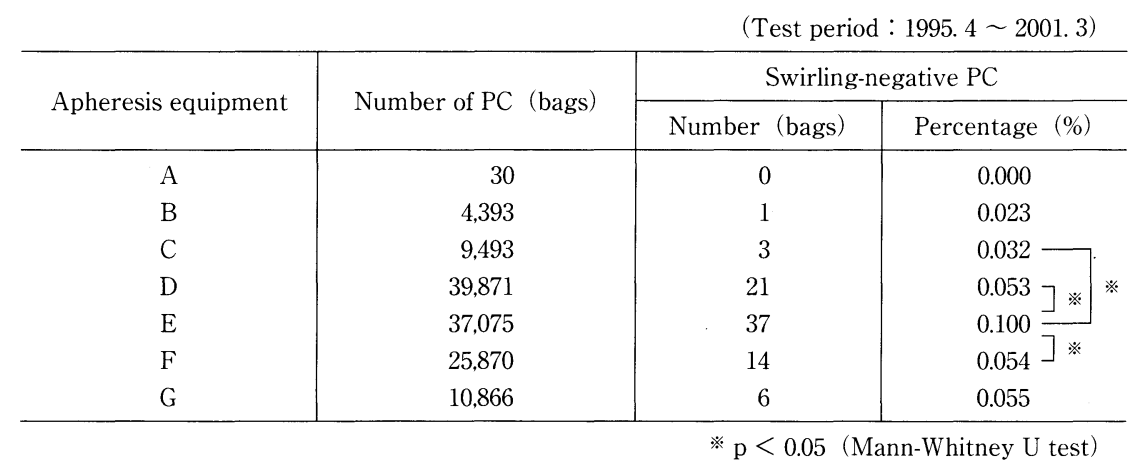

独立性のある場合には，Bonferroni 検定により群 間を比較し，危険率 $1 \%$ 未満を有意とした。装置 別の比較には Mann-Whitney 検定を行い, 危険率 $5 \%$ 未満を有意とした。性別の比較は，フィッ シャーの直接確率検定を用い危険率 $1 \%$ 未満を有 意とした。検查不合格 PC の血小板機能検査成績 の比較は, unpaired t-test を用い危険率 $5 \%$ 未満 を有意とした。

\section{結 果}

（1）スワーリング検査不合格 PC の発生状況 平成 7 年 4 月から 13 年 3 月までの 6 年間, ス ワーリング検査で不合格となった PC は 127,623 バッグ中 82 バッグ, 発生率は $0.064 \%$ であった (Table 1). 製剤別では 20 単位 PC が 82 バッグ中 40 バッグを占め, 10 単位 PC に比べて統計上, 有 意性をもって多く発生していた $(\mathrm{p}=0.003)$.

採血装置別のスワーリング検査不合格 PC の発 生率では, 装置 $\mathrm{E} て ゙$ 多く発生する傾向がみられた (Table 2). そこで, 同機種で採血された 20 単位
PCについて採取条件（処理血液量, 採取時間, ACD の使用量など)を比較したが，合格と不合格 の両者に違いはみられなかった（Table 3).

スワーリング検査が不合格であった PCのド ナーについて, 性別, 年齢別に比較した結果を Table 4 に示したが, 男性に比べ女性に多く発生して いた $(\mathrm{p}<0.001)$ ．年齢による発生率の差は見られ なかった.

スワーリング検查不合格となった PC のドナー について, 献血回数との関係を調べた. 調査期間 中, PC 献血を行ったドナーは, 26,577 名おり, そ のうち 58 名がスワーリング検査不合格 PCのド ナーであった (発生率 $0.218 \%$ ). 献血回数の増加に よる明らかな影響は確認されなかったものの, 検 查不合格ドナーの発生頻度は増加する傾向にあっ た (Table 5).

次にスワーリング検査不合格 PC のドナーが, 再度献血を行った場合に, その PC が不合格とな るか否かについて調べた，スワーリング検査不合 
Table 3 Conditions of collection of swirling-negative PC by Apheresis equipment $\mathrm{E}$

\begin{tabular}{l|c|c}
\hline \multirow{2}{*}{} & \multicolumn{2}{|c}{ Swirling test } \\
\cline { 2 - 3 } & Negative & Positive \\
\hline Number & 20 & 100 \\
Platelet count $\left(\times 10^{11} / \mathrm{bag}\right)$ & $4.7 \pm 0.4$ & $4.1 \pm 0.8$ \\
Volume $(\mathrm{mL})$ & $242.6 \pm 22.7$ & $259.2 \pm 21.3$ \\
Treated blood volume (mL) & $3.459 \pm 425$ & $3,678 \pm 563$ \\
N-N time (min) & $79 \pm 11$ & $80 \pm 10$ \\
ACD consumed (mL) & $367.3 \pm 50.0$ & $377.0 \pm 51.4$ \\
Centrifuge speed (rpm) & $1,400 \sim 1,600$ & $1,400 \sim 1,600$ \\
Critical flow (mL/min) & $35 \sim 50$ & $35 \sim 60$ \\
\hline \multicolumn{2}{|c}{}
\end{tabular}

Table 4 Frequency of swirling-negative PC classified by donor gender and age

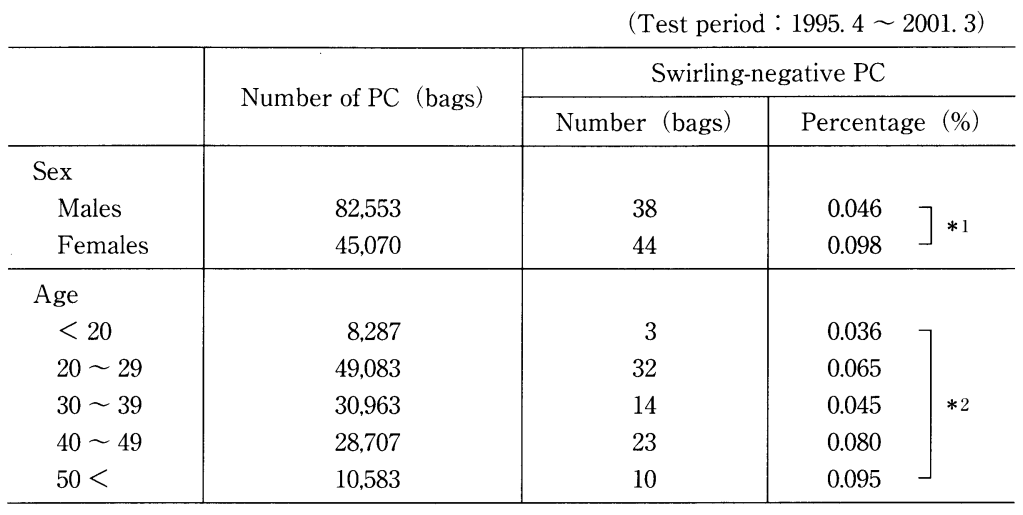

$*_{1}: \mathrm{p}<0.001$ (Fisher's exact probability test)

$* 2: \mathrm{p}=0.248\left(\chi^{2}\right.$ - test for independence $)$

格 PCのドナー 58 名中, PC 献血が 1 回のみで あったドナー（8名）を除いた 50 名について検討 したところ，複数回スワーリング検査不合格 PC が発生しているドナーは，12 名 (発生率 24\%) で あった。これら 12 名のドナーの内訳を Table 6 に示す. 献血回数は, 5 25 回で, 不合格回数は 2 5 回, 不合格の回数が 3 回以上のドナーが大半 （12人中 9 人）で，不合格率が $40 \%$ を超えるド ナーが 5 名存在した. 12 名の合計の献血回数は 141 回で, そのうちの 36 回 $(25.5 \%)$ が不合格で あった。

（2）不合格 PC の血小板機能

スワーリング検査が不合格で $\mathrm{pH}$ の測定が可能
であった PC（45 例）のうち, $\mathrm{pH}$ が 7.0 以上を示 した PC (33 例) の一部について血小板機能を調べ た（Table 7).スワーリング検査が合格であった $\mathrm{PC}$ と比べて，ADP 或いはコラーゲン刺激に対す る凝集能および\%HSR に差はみられなかった. 変 形能及び形態スコアーは，不合格 PCの方が有意 に低值であった $(\mathrm{P}<0.05)$ ） $\mathrm{P}$-セレクチン陽性率， $\beta$-TG は合格 PCに比べてやや高值を示したが有 意な差はみられなかった。 また，無菌試験の実施 が可能であった PC (25 例) について細菌污染の有 無を確認したところ, 結果はすべて陰性であった.

\section{考察}

スワーリング検查は以前から血小板の外観試験 
Table 5 Frequency of swirling-negative PC classified by frequency of donation

\begin{tabular}{c|c|c|c}
\hline \multicolumn{2}{c}{ (Test period : 1995. 4 2001. 3) } \\
\hline Donation & \multicolumn{2}{c}{ Swirling-negative PC } \\
\hline frequency) & (number) & Number (bags) & Percentage (\%) \\
\hline 1 & 10,607 & 8 & 0.075 \\
$3 \sim 5$ & 4,111 & 5 & 0.122 \\
$6 \sim 9$ & 5,571 & 18 & 0.323 \\
$10<$ & 2,783 & 16 & 0.575 \\
Total & 3,505 & 11 & 0.314 \\
\hline
\end{tabular}

Table 6 Background of donors whose PC failed the swirling test repeatedly

\begin{tabular}{c|c|c|c|c|c}
\hline \multirow{2}{*}{ ID No. } & \multirow{2}{*}{ Sex } & \multirow{2}{*}{ Age } & No. of donations & \multicolumn{2}{|c}{ Swirling-negative PC } \\
\cline { 4 - 6 } & & & & Number (bags) & Percentage (\%) \\
\hline 2 & F & 48 & 7 & 3 & 42.9 \\
5 & M & 42 & 7 & 3 & 42.9 \\
6 & M & 31 & 5 & 2 & 40.0 \\
9 & F & 23 & 11 & 3 & 27.3 \\
12 & M & 47 & 8 & 3 & 37.5 \\
13 & M & 52 & 9 & 4 & 44.4 \\
19 & F & 22 & 5 & 3 & 60.0 \\
25 & F & 21 & 13 & 2 & 15.4 \\
34 & F & 42 & 19 & 3 & 15.8 \\
40 & F & 25 & 25 & 5 & 20.0 \\
58 & F & 29 & 10 & 3 & 30.0 \\
73 & M & 20 & 22 & 2 & 9.1 \\
\hline
\end{tabular}

Table 7 Properties of platelets in swirling-negative PC showing normal $\mathrm{pH}$ range

\begin{tabular}{l|cc}
\hline \multirow{2}{*}{} & \multicolumn{2}{|c}{ Swirling test } \\
\cline { 2 - 3 } & Negative $(\mathrm{n}=8)$ & Positive $(\mathrm{n}=6)$ \\
\hline $\mathrm{pH}$ & $7.1 \pm 0.1$ & $7.2 \pm 0.1$ \\
Aggregation (\%) & & \\
Collagen $5 \mu \mathrm{g} / \mathrm{mL}$ & $85.3 \pm 12.4$ & $73.2 \pm 11.0$ \\
ADP $10 \mu \mathrm{M}$ & $52.7 \pm 12.0$ & $41.3 \pm 6.4$ \\
\%HSR & $80.5 \pm 7.7$ & $79.6 \pm 3.5$ \\
ESC ${ }^{* *}(\%$ increase O.D.) & $7.7 \pm 1.8 \quad-※-$ & $13.2 \pm 3.1$ \\
Morphology score & $12.8 \pm 19.2-\ldots-$ & $69.8 \pm 9.2$ \\
P-selectin positive ** (\%) & $1.1 \pm 0.1$ & $0.6 \pm 0.1$ \\
$\beta$-TG (ng/mL) & $3,273 \pm 1,459$ & $1,960 \pm 423$ \\
\hline
\end{tabular}

Extent of platelet shape change (mean $\pm \mathrm{SD}, \quad \% \mathrm{p}<0.05$ Student's t-test)

$* * \mathrm{n}=4$

の一つとして利用されている ${ }^{91111}$. 当センターで

は, 平成 7 年 4 月からスワーリング検査をルーチ ンに導入した。これまでの 6 年間の結果，不合格
PC の発生頻度は $0.064 \%$ であった（Table 1). BEST の検討では，13 施設で5,366 バッグを 3 日 間保存した PCについて調査を行い，0.0〜3.8\% 
（平均 $0.67 \% ）$ が不合格であったと報告されてい る ${ }^{6}$. そのなかで，成分採血由来 PC (305 バッグ) については, 3 施設で実施され，そのうち 2 施設で は不合格 PC が 0 であったが， 77 バッグ中 3 バッ グ $(3.8 \%)$ が不合格の施設もみられた。 スワーリ ング検査の判定は目視によるため，経験の浅い施 設では判定者のトレーニングが大切であり，熟練 度の違いが施設間でのばらつきに影響していると 思われる。これまで，スワーリング検査の機械化 への検討が行われてきた ${ }^{13) 122}$ が，未だ確立された 装置の開発には至っていない.

$\mathrm{PC}$ の採取時にスワーリングが消失する原因と しては，採取装置又は採取条件あるいはドナーに 由来する要因等が推定される，今回行った検討か ら, 不合格 PC の発生は, ある特定の装置や高単位 $\mathrm{PC} に$ 多く見られた.この理由を検討するため, 合 格と不合格 PC の採取条件および血小板数を比較 したが，両者に違いはなく, 不合格 PC 発生の明ら かな要因は見出せなかった。 ドナーの性別および 年齢別の発生頻度では, 男性に比べて女性に多く 発生していたが，その原因は明らかではない。一 方，スワーリング検査が不合格となった PCのド ナーが, 再度献血を行ったときに, その PC が不合 格になるか否かを調査したところ，一度不合格と なったドナーの $24 \%$ が, その後も何度か不合格と なっていた。 バッグ数にすると不合格 PC 全体の 約半数が, 2 回以上不合格となった PCのドナー 由来であったこのことから，スワーリングの消 失とドナー側の要因との関連が示唆された。ス ワーリングが弱い PC の内因性セロトニン含量が 低いという報告もあり ${ }^{13)}$ ，ドナーに起因する要素 と不合格 PCの発生の関連については，今後さら に検討を重ねていく必要があると考える.

従来, $\mathrm{PC}$ は細菌污染 ${ }^{14)}$ あるいは低温又は低 $\mathrm{pH}$ の保存下でスワーリングが消失すると言われてき た 。今回の場合, 無菌試験を全例に実施したわけ ではないが，可能であった PC は全て細菌検査陰 性であり, 細菌污染が原因とは考えにくい. BEST の検討結果 ${ }^{6}$ によると, 保存 3 および 5 日目の判定 においてスワーリング不合格 PC の大半が $\mathrm{pH} 6.4$ 以下または $\mathrm{pH} 7.5$ 以上であった。これまで $\mathrm{pH} の$
低下に伴ったスワーリング不合格 PCの検討で は, \%discs 以外の項目においても血小板の品質低 下を裏付ける異常值を示し, in vivo での生存率は 低いとされている7).さらに,このようなスワーリ ング不合格 PC の輸血後の補正血小板増加数 （CCI：corrected count increment）が著しく低い こと, また非溶血性輸血副作用の発生頻度が有意 に高いことが Bertolini ら ${ }^{15}$ によって報告されて いる. 今回我々は, 低 pH-PC 例の血小板機能につ いては，詳細な検討を行わなかったが, 清水ら 報告にもあるような同様の機能異常がみられたも のと推定される.

一方, BEST の検討では, $\mathrm{pH}$ が維持されている にもかかわらずスワーリングが消失した例も報告 されているが，そのような PC の性状は明らかで はない.そこで，採血後 1 日目に $\mathrm{pH}$ が 7.0 以上で スワーリング不合格となった PC の血小板機能を 測定した。これらの PC は正常 PCに比べて変形 能が低く, morphology scoreの変化すなわち\% discs が低值であることが確認された. しかし，そ の他の機能は正常 PCに比較して有意な変化は認 められなかった。 \% discsの減少が活性化血小板の 増加あるいは凝集能の変化としてとらえられな かったのは, 機能検査の条件 (惹起物質の濃度)や 活性化マーカーの感度による可能性も考えられ る.今回の検討に用いた正常 $\mathrm{pH}$ 範囲にあるス ワーリング不合格 PC は，その後 4 日間保存して も $\mathrm{pH}$ の低下は認められなかった.このような $\mathrm{PC}$ が生体内での生存率の低下に結びっくか否かは明 らかではないが, PRP-PC の自己血輸血の際に, 正 常 $\mathrm{pH}$ 範囲にありながらスワーリング不合格と なった PC は生体内での生存率が低いという報告 がある ${ }^{16)}$.このようなことから，正常 $\mathrm{pH}$ 範囲に ありスワーリング不合格の PC が，臨床的に使用 可能か否かについては，今後さらに検討が必要と 考える。

謝辞 : 今回の研究を行うにあたり, 統計学解析をご指導 いただきました金子雅一博士に感謝いたします.

\section{文 献}

1) Frantantoni, J.C., Poindexteret, B.J., Bonner, R. F. : Quantitative assessment of platelet morphol- 
ogy by scattering: A potential method for the evaluation of platelets for transfusion. J. Lab. Clin. Med., $103: 621-631,1984$.

2）清水哲夫, 打桐千鶴子, 佐野 薰, NG JUNG YI, 中村定生, 石川裕子, 阿部裕司, 船戸悦二, 水野 伸一, 中島 武, 神谷 忠, 大久保幸雄 : 簡便に おこなえる血小板製剤の外観試験法一swirling pattern test一. 日本輸血学会雑誌, 41(3)：207212, 1995.

3) George, V., Hoime, S., Moroff, G. : Evaluation of two instruments for noninvasive platelet concentrate quality assessment. Transfusion, $29: 273-$ $275,1989$.

4) Bertolini, F., Murphy, S. : A multicenter evaluation of reproducibility of swirling in platelet concentrates. Transfusion, $34: 796-801,1994$.

5) Holme, S., Vaidja, K., Murphy, S. : Platelet storage at $22^{\circ} \mathrm{C}$ : effect of type of agitation on morphology, viability, and function in vitro. Blood 52 : 425-435, 1978.

6) Bertolini, F., Murphy, S. : A multicenter inspection of the swirling phenomenon in platelet concentrates prepared in routine practice. Transfusion, 36 : 128-132, 1996.

7) Kunicki, T.J., Tuccelli, M., Becker, G.A., Aster, R. H. : A study of variables affecting the quality of platelets stored at "room temperature" Transfusion, 15:414-421, 1975.

8) Fijnheer, R., Modderman, P.W., Veldman, H., Ouwehand, W.H., Nieuwenhuis, H.K., Roos, D., Korte. D. : Detection of platelet activation with monoclonal antibodies and flow cytometry. Transfusion, $30: 20-25,1990$.

9) Pietersz, R., Reesink, H., Dekker, W.J.A. : Prepa- ration of leukocyte-poor platelet concentrates from buffycoats. II. Lack of effect on storage of platelet concentrates. Vox Sang, $53: 208-213$, 1987.

10) Fijnheer, R., Pietersz, R.N.I., D. dekorte Roos, D. : Monitoring of platelet morphology during storage of platelet concentrates. Transfusion, $29: 36-40$, 1989.

11）飯田俊二, 川村 薫, 岡田基文, 平井建策 : Swirling Pattern による濃厚血小板の品質管理. 日赤薬 剂師会会誌, 58：98-100, 1990 .

12）秋野光明, 新保雅之, 関口定美, 久保田文雄, 中 本博幸, 岡田徳弘：自動スワーリング判定装置の 評価一フローイメージサイトメータの応用一. 医 科器械学, $68: 607-612,1998$.

13) Hervig, T., Bakken, A.M., Farstad, M. : The swirling phenomenon in stored platelets is influenced by their endogenous serotonin. Transfusion Medicine, $9: 139-145,1999$.

14）三谷孝子, 橋本浩司，千葉眞彰，池淵研二，関口 定美：濃厚血小板製剂の細菌污染一血小板献血 由来血小板製剂で経験した一症例. 日本輸血学会 雑誌, 42 (6)：294-298, 1996.

15) Bertolini, F., Agazzi, A., Peccatori, F., Martinelli G. Sandri, T.M. : The absence of swirling in platelet concentrates in highly predictive of poor posttransfusion platelet count increments and increased risk of a transfusion reaction. Transfusion, $40: 121-122,2000$.

16) Ross, D., Holme, S., Hartman, P., Reece, K., Cubilla, L., Heaton, A. : A quick visual method for quality control of platelet concentrates (abstract). Transfusion, $26: 550,1986$. 